\title{
Proinflammatory cytokines induce rapid, NO-independent apoptosis, expression of chemotactic mediators and interleukin-32 secretion in human pluripotent stem cell-derived beta cells
}

\author{
Rabea Dettmer ${ }^{1} \cdot$ Isabell Niwolik ${ }^{1} \cdot$ Karsten Cirksena $^{1} \cdot$ Toshiaki Yoshimoto $^{1,2} \cdot$ Yadi Tang $^{1} \cdot$ Ilir Mehmeti $^{1}$. \\ Ewa Gurgul-Convey ${ }^{1} \cdot$ Ortwin Naujok $^{1}$
}

Received: 21 July 2021 / Accepted: 23 November 2021 / Published online: 5 February 2022

(C) The Author(s) 2022

\begin{abstract}
Aims/hypothesis The aim of this study was to examine the effects of proinflammatory cytokines on cells of different developmental stages during the generation of stem cell-derived beta cells (SC-beta cells) from human pluripotent stem cells (hPSCs). We wanted to find out to what extent human SC-beta cells are suitable as an experimental cellular model and, with regard to a possible therapeutic use, whether SC-beta cells have a comparable vulnerability to cytokines as bona fide beta cells.

Methods hPSCs were differentiated towards pancreatic organoids (SC-organoids) using a 3D production protocol. SC-beta cells and non-insulin-producing cells were separated by FACS and differential gene expression profiles of purified human SC-beta cells, progenitor stages and the human beta cell line EndoC- $\beta \mathrm{H} 1$, as a reference, were determined after $24 \mathrm{~h}$ incubation with the proinflammatory cytokines IL- $1 \beta$, TNF- $\alpha$ and IFN- $\gamma$ via a transcriptome microarray. Furthermore, we investigated apoptosis based on caspase cleavage, the generation of reactive oxygen species and activation of mitogen-activated protein-kinase (MAPK) stress-signalling pathways.

Results A $24 \mathrm{~h}$ exposure of SC-beta cells to proinflammatory cytokines resulted in significant activation of caspase $3 / 7$ and apoptosis via the extrinsic and intrinsic apoptosis signalling pathways. At this time point, SC-beta cells showed a markedly higher sensitivity towards proinflammatory cytokines than non-insulin-producing cells and EndoC- $\beta \mathrm{H} 1$ cells. Furthermore, we were able to demonstrate the generation of reactive oxygen species and rule out the involvement of NO-mediated stress. A transient activation of stress-signalling pathways p38 mitogenactivated protein kinases (p38) and c-Jun N-terminal kinase (JNK) was already observed after 10 min of cytokine exposure. The transcriptome analysis revealed that the cellular response to proinflammatory cytokines increased with the degree of differentiation of the cells. Cytokines induced the expression of multiple inflammatory mediators including IL-32, CXCL9 and CXCL10 in SC-beta cells and in non-insulin-producing cells.

Conclusions/interpretation Our results indicate that human SC-beta cells respond to proinflammatory cytokines very similarly to human islets. Due to the fast and fulminant cellular response of SC-beta cells, we conclude that SC-beta cells represent a suitable model for diabetes research. In light of the immaturity of SC-beta cells, they may be an attractive model for developmentally young beta cells as they are, for example, present in patients with early-onset type 1 diabetes. The secretion of chemotactic signals may promote communication between SC-beta cells and immune cells, and non-insulin-producing cells possibly participate in the overall immune response and are thus capable of amplifying the immune response and further stimulating inflammation. We demonstrated that cytokine-treated SC-organoids secrete IL-32, which is considered a promising candidate for type 1 diabetes onset. This underlines the need to ensure the survival of SC-beta cells in an autoimmune environment such as that found in type 1 diabetes.
\end{abstract}

Ortwin Naujok

naujok.ortwin@mh-hannover.de

1 Institute of Clinical Biochemistry, Hannover Medical School, Hannover, Germany

2 Department of Digestive and Transplant Surgery, Tokushima University, Tokushima, Japan 


\section{Research in context}

\section{What is already known about this subject?}

- The differentiation of human pluripotent stem cells towards human pancreatic beta cells (stem cell-derived beta cells [SC-beta cells]) is possible, but produces a heterogeneously composed cell population, hindering the exclusive look at SC-beta cells

- SC-beta cells offer a platform for therapeutic development and disease modelling as they share many human beta cell properties

- In type 1 diabetes, the autoimmune-mediated destruction of beta cells involves multiple mechanisms including cell-cell interactions with immune cells and secretion of proinflammatory mediators

\section{What is the key question?}

- What are the effects of proinflammatory cytokines on purified SC-beta cells, non-insulin-producing cells and their developmental precursors?

What are the new findings?

- The response to proinflammatory cytokines increased with the degree of differentiation

- The cytokine-mediated effects on SC-beta cells led to NO-independent apoptosis and revealed similar gene regulation patterns as in human islets

- Non-insulin-producing pancreatic cells possibly participate in the acceleration of inflammation

\section{How might this impact on clinical practice in the foreseeable future?}

- The response of beta cells to proinflammatory cytokines is similar to that of human islets regarding the changes in signalling cascades and gene expression patterns. Therefore, SC-beta cells represent a suitable cellular human beta cell model for diabetes research. However, their high sensitivity to proinflammatory cytokines could be an obstacle that should be considered when using these cells for therapeutic purposes

Keywords Apoptosis $\cdot$ Cytokines $\cdot$ Differentiation $\cdot$ Immune response $\cdot$ Inflammation $\cdot$ Pancreatic beta cells $\cdot$ Stem cell-derived beta cells · Type 1 diabetes

$\begin{array}{ll}\text { Abbreviations } & \\ \text { CHOP } & \text { C/EBP homologous protein } \\ \text { d } & \text { Day } \\ \text { DCFDA } & \text { Dichlorofluorescein diacetate } \\ \text { DE } & \text { Definitive endoderm } \\ \text { EO-T1D } & \text { Early-onset type 1 diabetes } \\ \text { ER } & \text { Endoplasmic reticulum } \\ \text { ERK } & \text { Extracellular-signal regulated kinase } \\ \text { GO } & \text { Gene ontology } \\ \text { hPSC } & \text { Human pluripotent stem cell } \\ \text { IFNGR1 } & \text { IFN gamma receptor 1 } \\ \text { IL1R1 } & \text { IL1 receptor 1 } \\ \text { INS } & \text { Insulin } \\ \text { IPA } & \text { Qiagen Ingenuity Pathway Analysis } \\ \text { iPSC } & \text { Induced pluripotent stem cell } \\ \text { JNK } & \text { c-Jun N-terminal kinase } \\ \text { L-NNA } & \text { Nitro-L-arginine } \\ \text { MACS } & \text { Magnetic-activated cell sorting } \\ \text { MAPK } & \text { Mitogen-activated protein-kinase } \\ \text { MPC } & \text { Multipotent pancreatic progenitor cell }\end{array}$

Abbreviations

$$
\text { d }
$$

\section{DCFDA}

$\mathrm{DE}$

EO-T1D

ER

ERK

GO

hPSC

IFNGR1

IL1R1

INS

IPA

iPSC

JNK

L-NNA

MPC

$\begin{array}{ll}\text { p38 } & \text { p38 mitogen-activated protein kinases } \\ \text { PCA } & \text { Principal component analysis } \\ \text { PRR } & \text { Pattern recognition receptor } \\ \text { RNA-seq } & \text { RNA sequencing } \\ \text { ROS } & \text { Reactive oxygen species } \\ \text { RT-qPCR } & \text { Quantitative PCR with reverse } \\ & \text { transcription } \\ \text { SC-beta cell } & \text { Stem cell-derived beta cell } \\ \text { SC-organoids } & \text { Stem cell-derived pancreatic organoids } \\ \text { SOX9 } & \text { SRY-box transcription factor 9 } \\ \text { STAT1 } & \text { Signal transducer and activator } \\ & \text { of transcription 1 } \\ \text { TLR } & \text { Toll-like receptor } \\ \text { TNFR1 } & \text { TNF receptor 1 }\end{array}$

\section{Introduction}

Type 1 diabetes is a chronic autoimmune disease characterised by loss of insulin production resulting from the selective and 
progressive destruction of beta cells. Activated immune cells infiltrate the islets of Langerhans and mediate their harmful effects through soluble cytotoxic mediators and cell-cell contacts. Proinflammatory cytokines, such as IL- $1 \beta$, TNF- $\alpha$ and IFN- $\gamma$, are considered to be major mediators for the destruction of beta cells [1-3]. As a result of the cytokine stimulus various signal transducers, such as the transcription factors signal transducer and activator of transcription 1 (STAT1), NF-kB and interferon regulatory factor 1 (IRF-1) $[3,4]$, are activated, leading to oxidative stress, endoplasmic reticulum (ER) stress and apoptosis. ER stress, IL-1 and/or TNF can also induce the stress-signalling pathways c-Jun Nterminal kinase (JNK) and p38 mitogen-activated protein kinases (p38) [5-7]. In a vicious circle, cytokine exposure induces expression of MHC class I and II proteins and secretion of cytokines and chemokines such as chemokine (C-X-C motif) ligand 9/10 (CXCL9/10), CC-chemokine ligand 2/3/5/ 8 (CCL2/3/5/8) and others by beta cells, thereby promoting a destructive dialogue between immune cells and beta cells, resulting in acceleration of islet inflammation (insulitis) $[8,9]$.

The main cause of beta cell death is apoptosis. However, the mechanism of beta cell apoptosis and death in type 1 diabetes is not yet fully understood. This is partly caused by substantial species differences in the pathomechanism between rodents and humans $[10,11]$ and also because of the limited availability of human islets for research. Human pluripotent stem cells (hPSCs) can be differentiated into beta cells $[12,13]$. Such stem cell-derived beta cells (SC-beta cells) are a promising donor-independent cellular model for research and drug development. Although SC-beta cells share many characteristics with human islet beta cells [13], they are phenotypically assigned to fetal perinatal beta cells due to their, in comparison with bona fide human beta cells, poorer glucose-stimulated insulin secretion, lack of biphasic insulin secretion and insufficient glucokinase and/or GLUT1/2 expression [14, 15]. SC-beta cells are also a possible source for cell replacement therapy of type 1 diabetes and type 2 diabetes $[16,17]$. In type 1 diabetes in particular, the immune system represents a hurdle for cell replacement therapy because the immunity acquired against beta cell-specific antigens is retained after the body's own beta cells are lost and this may cause another attack on transplanted SC-beta cells. In this environment with persistent autoimmunity an encapsulation of stem cell implants is thought to provide an immune protective environment while containing possible tumorigenic cells [18]. Soluble mediators, such as proinflammatory cytokines, could, however, overcome the encapsulation barrier [19]. So far only one pioneering study has dealt with the question of cytokine toxicity using heterogeneously composed stem cellderived pancreatic organoids (SC-organoids) [20]. However, directed differentiation does not exclusively generate SC-beta cells but also other pancreatic and non-pancreatic cell populations [21]. In order to address the problem of heterogeneity, we have recently developed dual reporter hESC lines (SOX9 [SRY-box transcription factor 9]-GFP2/H-2K ${ }^{\mathrm{K}}$ [H-2 class I histocompatibility antigen, K-K alpha chain], insulin [INS]mCherry) [22]. This allowed us to assign the effects of our experiments to SC-beta cells in a highly specific manner and to differentiate them from other cell types.

\section{Methods}

Human cell culture Routine culturing of the mycoplasmanegative human reporter ESC lines HES-3 SC30 ICNC4 and HES-3 SC30 [22] and the parental cell line HES-3 ('ESC', ES Cell International [ESIBI], Singapore) was performed on Matrigel-coated (Corning, Amsterdam, the Netherlands) sixwell plates using mTeSR1 medium (Stem Cell Technologies, Cologne, Germany). The culture of EndoC- $\beta \mathrm{H} 1$ cells was performed according to the standard protocol [23]. Differentiation was performed as described before [22] (Fig. 1a) and differentiation efficiency was monitored with the help of the reporter cell lines via flow cytometry (Fig. 1b, c). For further information, see the electronic supplementary material (ESM) Methods.

Gene expression analysis, transcriptome analysis, western blot For gene expression analysis, the cell line HES-3 SC30 ICNC4 was used. RNA was isolated using the MachereyNagel Nucleospin RNA Plus Kit (Macherey-Nagel, Düren, Germany). RevertAid H Minus M-MuLV Reverse Transcriptase (Thermo Fisher Scientific, Schwerte, Germany) and random hexamer primers (Thermo Fisher Scientific) were used to synthesise cDNA from 500-2000 ng of total RNA. SYBR Green-based quantitative PCR reactions were measured as described in detail in the ESM Methods. Primer sequences are listed in ESM Table 1.

Whole transcriptome microarray analysis was performed by the central facility 'Genomics' of the Hannover Medical School, as described in detail in the ESM Methods and ESM Fig. 1.

For western blot analysis, cells derived from HES-3 SC30 were used and protein expression was analysed as described in detail in the ESM Methods. Antibodies are listed in ESM Table 2.

Flow cytometry and cell sorting FACS was carried out by the central cell sorting facility of the Hannover Medical School. Flow cytometry and magnetic-activated cell sorting (MACS) were done as described in detail in the ESM Methods.

Cytokine treatment, apoptosis assessment, and measurement of NO and ROS Cells were treated with a common cytokine mix containing $185 \mathrm{U} / \mathrm{ml} \mathrm{TNF}-\alpha, 60 \mathrm{U} / \mathrm{ml} \mathrm{IL}-1 \beta$ and $14 \mathrm{U} / \mathrm{ml}$ IFN- $\gamma$ (all ReliaTech, Wolfenbüttel, Germany) [1, 24] for 
a
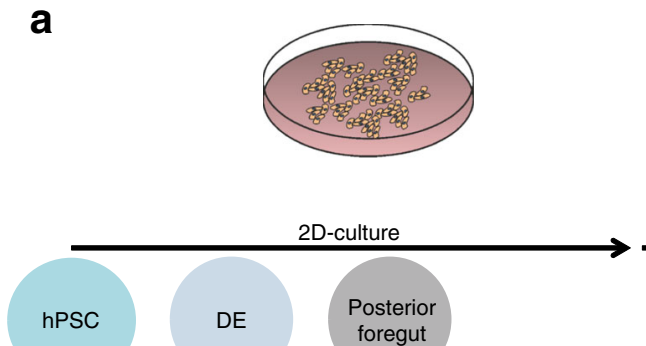

\begin{tabular}{|c|c|c|c|} 
d0-4 & d4-8 & d8-9 \\
Stage 1 & Stage 2 & Stage 39-12 \\
\hline Activin A & FGF7 & FGF10 \\
CHIR & IWR-1 & SANT-1 \\
& ATRA & ATRA \\
& LDN & IWR-1 \\
& & LDN \\
& & &
\end{tabular}

d

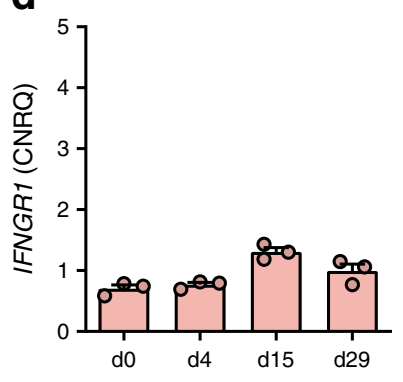

e

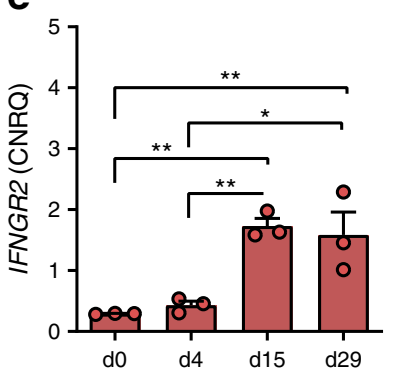

h
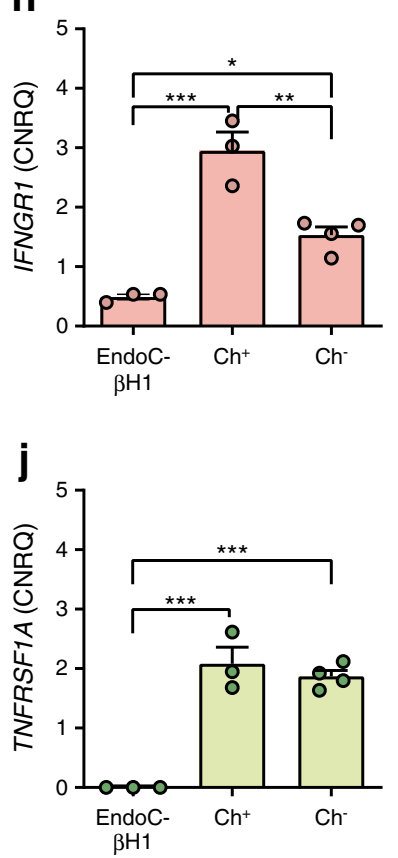

i

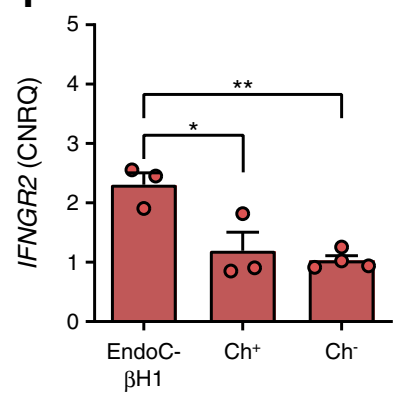

k

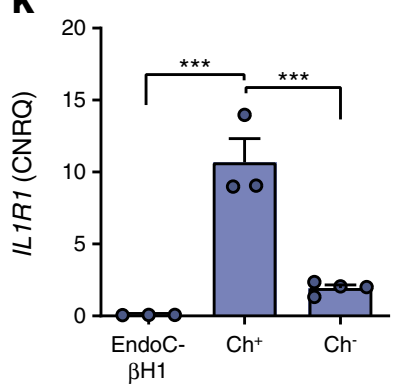

b
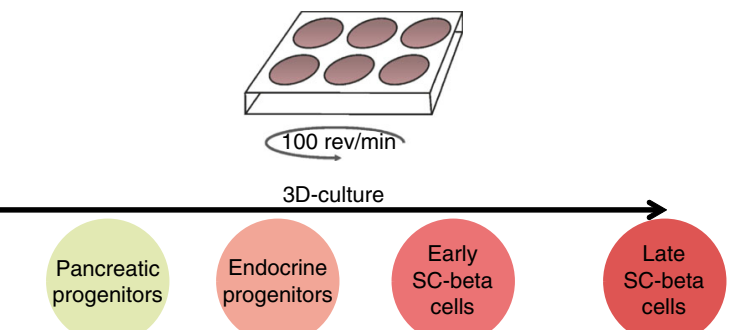

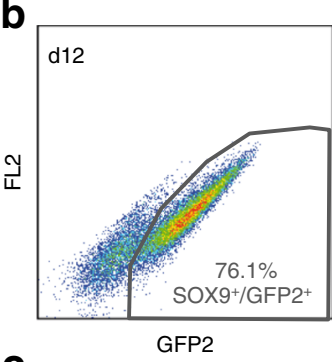

C

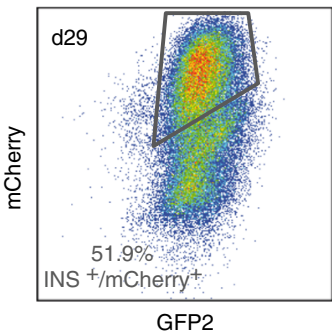

f

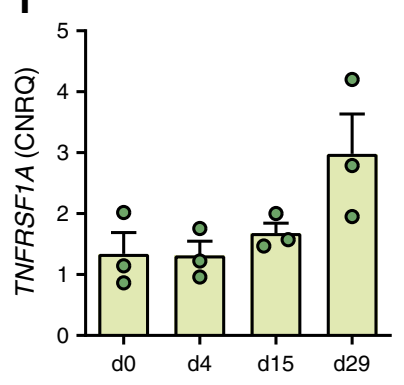

g

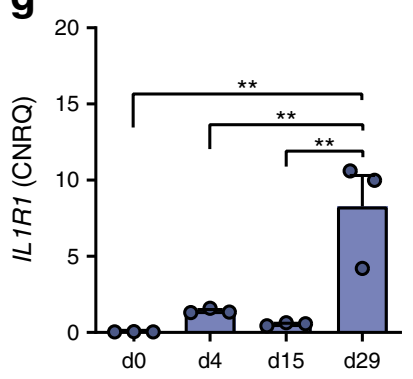


Fig. 1 Cytokine receptor expression in human SC-beta cells and their progenitors. (a) Schematic presentation of the differentiation protocol used in this study. (b, c) Example flow cytometric dot plots of SOX9/GFP2-expressing cells on d12 of differentiation (b) and INS/ mCherry-expressing cells on d29 of differentiation (c). (d-g) RT-qPCR analysis of cytokine receptor expressions of IFNGR1 (d), IFNGR2 (e), TNFRSF1A (f) and ILIRI (g) on d0 (hPSCs), d4 (DE), d15 (MPCs) and d29 (SC-organoids) of differentiation. Values are means \pm SEM. ${ }^{*} p<0.05, * * p<0.01, * * * p<0.001, n=3$. ANOVA plus Tukey's posttest. (h-k) RT-qPCR analysis of IFNGRI (h), IFNGR2 (i), TNFRSF1A (j) and $I L I R I(\mathbf{k})$ receptor expression of sorted $\mathrm{mCherry}^{+}$and mCherry ${ }^{-}$ cells on $\mathrm{d} 28$ of differentiation in comparison with EndoC- $\beta \mathrm{H} 1$ cells. Values are means \pm SEM. $* p<0.05, * * p<0.01, * * * p<0.001, n=3-4$. ANOVA plus Tukey's post-test. (I) Representative western blots and densitometry analysis of IL1R1, IFNGR1 and TNFR1 expression in different developmental stages of untreated (untr) and $24 \mathrm{~h}$ cytokinetreated (Mix) cells. Protein expression is normalised to actin and values are means \pm SEM. $n=3-4$. Alk5i, Alk5 inhibitor; ATRA, all trans retinoic acid; Ch, mCherry; CHIR, CHIR99021; CNRQ, calibrated normalised relative quantity; FGF, fibroblast growth factor; FL2, fluorescence channel 2 (575 nm); GC1, thyroid hormone receptor betaspecific agonist GC1; IWR-1, Wnt pathway inhibitor IWR-1; LDN, LDN193189; NA, nicotinamide; ROCKi, ROCK inhibitor Y-27632; SANT1, Sonic hedgehog signalling inhibitor; XXI, gamma-secretase inhibitor XXi

$12 \mathrm{~h}, 24 \mathrm{~h}$ or $48 \mathrm{~h}$ in their respective differentiation or culture media. Apoptosis was assessed using the Caspase-Glo 3/7, the Caspase-Glo 8 or the Caspase-Glo 9 Assay Systems or the RealTime-Glo Annexin V Apoptosis Assay (all Promega, Walldorf, Germany) according to the manufacturer's instructions. For details see the ESM Methods.

NO was measured as accumulated nitrite in the medium by the Griess reaction and intracellular reactive oxygen species (ROS) were estimated using the fluorescent probe dichlorofluorescein diacetate (DCFDA, Thermo Fisher Scientific), as described in detail in the ESM Methods. Definitive endoderm (DE) cells were derived from HES-3 and SC-organoids were derived from HES-3 SC30 ICNC4.

ELISA IL-32 Secreted IL-32 from SC-organoids (derived from HES-3 SC30 ICNC4) or EndoC- $\beta$ H1 cells was measured with the human IL-32 ELISA Kit (ELISAGenie, London, UK) according to the manufacturer's instructions.

Statistics Data are expressed as means \pm SEM unless stated otherwise. Statistical analyses were performed by GraphPad PRISM 8 (San Diego, CA, USA) using two-tailed paired Student's $t$ test or one-way ANOVA followed by Tukey's post-test. For details, see the ESM Methods.

Ethics approval The author's institution holds a license for the import and usage of human embryonic stem cells for the studies conducted in this manuscript (Robert Koch Institute, Berlin, Germany, AZ:1710-79-1-4-8E4).

\section{Results}

To determine the responsiveness of the cells to the proinflammatory cytokines IL- $1 \beta$, TNF- $\alpha$ and IFN- $\gamma$, we first analysed the expression of their corresponding receptors during the course of differentiation towards stem cell-derived organoids (SC-organoids) in comparison with the widely used human EndoC- $\beta \mathrm{H} 1$ beta cell line [25]. All receptors were expressed (Fig. 1d-g) and especially the expression of IL1 receptor 1 (IL1R1) increased significantly in SC-organoids (Fig. 1g). The insulin-producing SC-beta cells were purified with the help of an integrated mCherry reporter, whose expression is controlled by the insulin promoter. In a comparative analysis (Fig. 1h-k), especially ILIRI expression in $\mathrm{mCherry}^{+} /$insulinproducing SC-beta cells was increased compared with the mCherry ${ }^{-}$/non-insulin-producing population (Fig. 1k). The gene expression results could also be confirmed by western blot and densitometry analysis of the cytokine receptors IFN gamma receptor 1 (IFNGR1), IL1R1 and TNF receptor 1 (TNFR1) (Fig. 11).

To assess the cytokine sensitivity of the cells, we investigated caspase $3 / 7$ activation after a $24 \mathrm{~h}$ cytokine treatment in various developmental stages (Fig. 2a, b). In DE cells a 1.8fold and in SC-beta cells a threefold increased caspase 3/7 activation could be observed upon incubation with proinflammatory cytokines (Fig. 2b). In DE cells, the caspase 3/7 activation observed after $24 \mathrm{~h}$ (Fig. 2b, c) increased further after a longer, $48 \mathrm{~h}$ cytokine exposure, albeit not to a significant extent ( $p=0.061$ ) (Fig. 2c). Furthermore, a 1.6-fold caspase 8 (Fig. 2d) and a 1.4-fold caspase 9 (Fig. 2e) activation in DE cells could be determined after $12 \mathrm{~h}$. We could not observe any activation of caspase $3 / 7$ after $24 \mathrm{~h}$ in the reference human beta cell line EndoC- $\beta$ H1. In stem cell-derived cells caspase $3 / 7$ activation was almost exclusively limited to the mCherry ${ }^{+}$ population when compared with mCherry ${ }^{-}$cells, which showed no significant increase (Fig. 2b). Unsorted SCorganoids, without a reporter gene in the insulin-locus (HES-3 SC30), showed a significant 1.8-fold increase in caspase $3 / 7$ activity (Fig. 2f). The caspase $3 / 7$ activation of mCherry ${ }^{+}$cells observed after $24 \mathrm{~h}$ (Fig. $2 \mathrm{~b}-\mathrm{g}$ ) remained at the same level after $48 \mathrm{~h}$ (Fig. 2g). Furthermore, we found strong caspase 8 and 9 activations (both fourfold) after $12 \mathrm{~h}$ of cytokine exposure (Fig. 2h, i). Additionally, apoptosis was confirmed by annexin $\mathrm{V}$ binding after $24 \mathrm{~h}$ of cytokine treatment in SC-organoids. Accordingly, no increase in annexin V binding was observed in EndoC- $\beta \mathrm{H} 1$ cells (Fig. $2 \mathrm{j}$ ). Since DE cells and SC-beta cells were sensitive to cytokines, we estimated the overall generation of ROS in these cells after cytokine incubation (Fig. 2k-1). In order to determine the contribution of NO in the total amount of ROS detected by DCFDA oxidation, we added the nitric oxide synthase (NOS) inhibitor nitro-L-arginin (L-NNA). In DE cells the increase (1.5-fold) in total ROS generation after cytokine exposure was slightly 
a

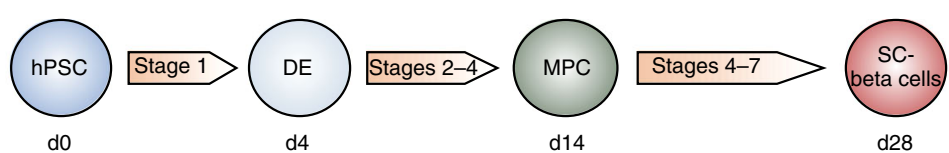

$\begin{array}{lccc}\begin{array}{l}\text { pluripotent } \\ \text { stem cells }\end{array} & \begin{array}{c}\text { definitive } \\ \text { endoderm }\end{array} & \begin{array}{c}\text { multipotent pancreatic } \\ \text { progenitors }\end{array} & \begin{array}{c}\text { stem cell-derived } \\ \text { beta cells }\end{array}\end{array}$

Toxicity assay
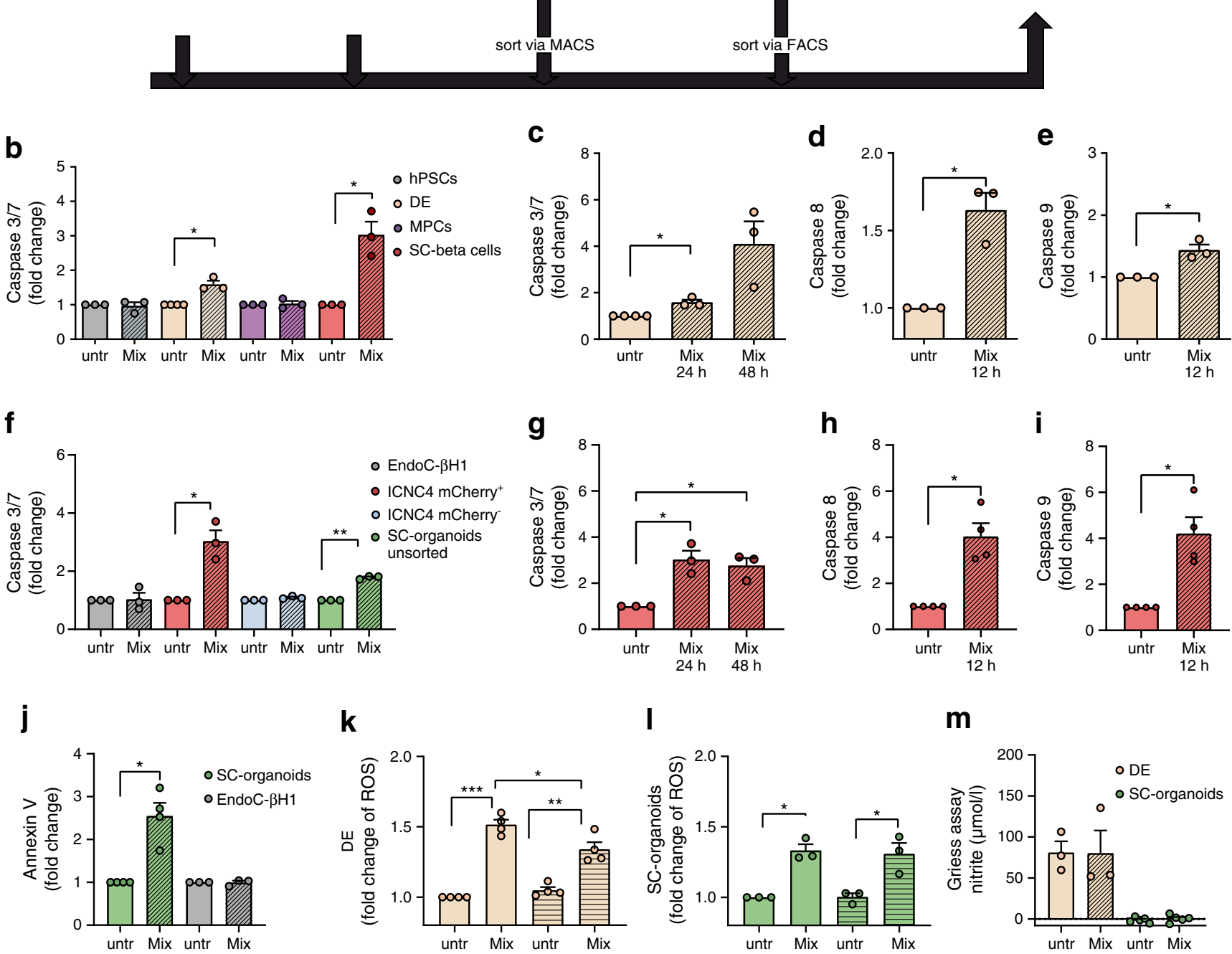

k

I

m
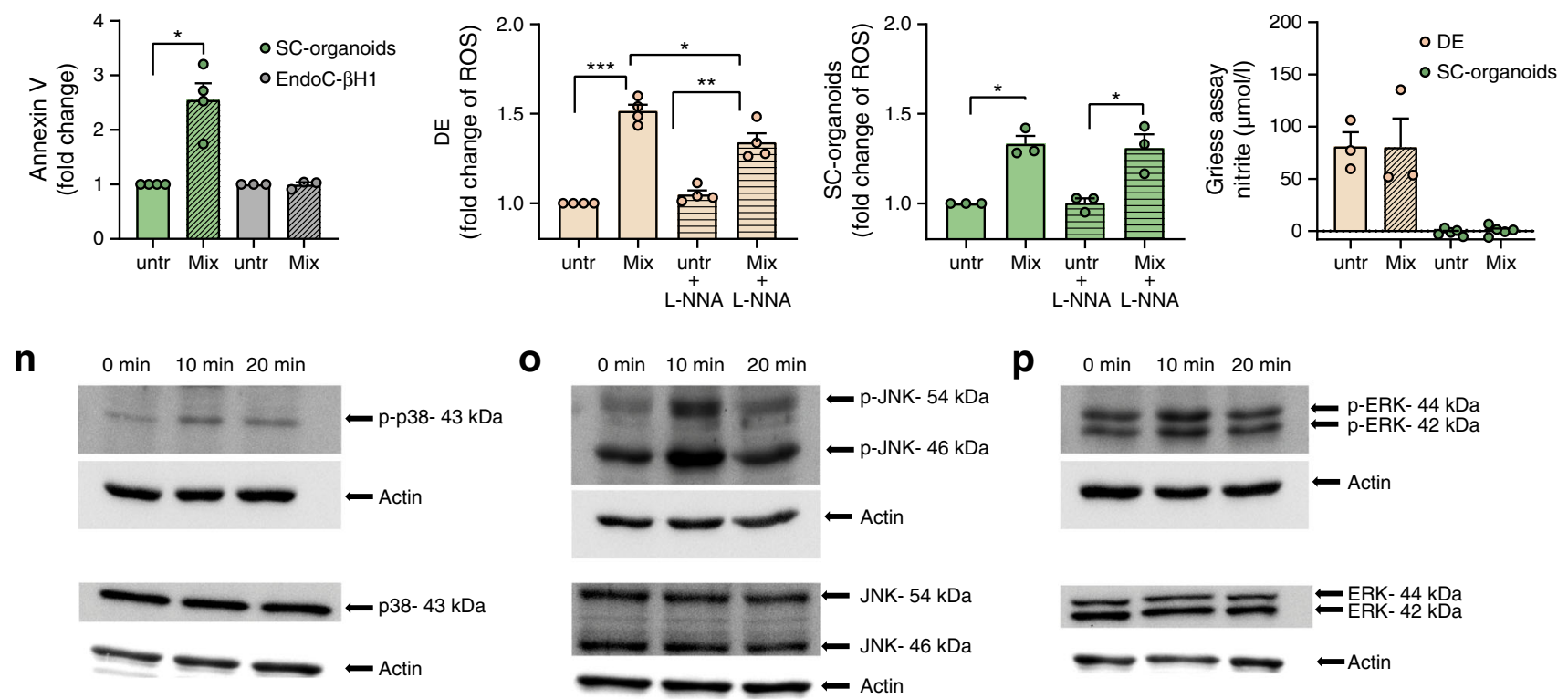

reduced with the addition of L-NNA (Fig. 2k), unlike in SCbeta cells, whose increase in ROS generation (1.3-fold) was not influenced by L-NNA (Fig. 21). In addition, we measured $\mathrm{NO}$ as accumulated nitrite in the medium by the Griess reaction and found no increase in $\mathrm{NO}$ in the supernatants of cytokine-treated compared with untreated cells after $24 \mathrm{~h}$, either for DE cells or for unsorted SC-organoids (Fig. 2m). However, it is noticeable that the basic level of NO in DE cells was already somewhat elevated (Fig. $2 \mathrm{~m}$ ). Next, we investigated the induction of mitogen-activated protein-kinase 
Fig. 2 Assessment of cytokine toxicity and apoptosis signalling. (a) Schematic presentation of hPSC differentiation towards SC-beta cells and time points for toxicity tests. (b) Analysis of caspase 3/7 activation of $24 \mathrm{~h}$ cytokine-treated cells (Mix) compared with untreated cells (untr) on hPSCs (d0), DE (d4), MPCs (d14) and sorted SC-beta cells (d28). Values are means \pm SEM. ${ }^{*} p<0.05, n=$ 3. Two-tailed, paired Student's $t$ test. (c) Analysis of caspase 3/7 after $24 \mathrm{~h}$ and $48 \mathrm{~h}$ and caspase 8 (d) and 9 (e) activation (after $12 \mathrm{~h}$ ) in cytokine-treated vs untreated DE cells. Values are means \pm SEM. ${ }^{*} p<0.05, n=3$. Two-tailed, paired Student's $t$ test. (f) Comparison of caspase 3/7 activation of cytokine-treated vs untreated EndoC$\beta \mathrm{H} 1$-cells, sorted mCherry ${ }^{+}$and $\mathrm{mCherry}^{-}$cells of the cell line HES3 SC30 ICNC4 and unsorted pancreatic organoids of the cell line HES3 SC30. Values are means \pm SEM. $* p<0.05$, $* * p<0.01, n$ $=3$. Two-tailed, paired Student's $t$ test. (g) Analysis of caspase 3/7 after $24 \mathrm{~h}$ and $48 \mathrm{~h}$ and caspase 8 (h) and 9 (i) activation after $12 \mathrm{~h} \mathrm{in}$ cytokine-treated vs untreated sorted SC-beta cells. Values are means \pm SEM. ${ }^{*} p<0.05, n=3-4$. Two-tailed, paired Student's $t$ test. (j) Confirmation of apoptosis assessment in SC-organoids and EndoC$\beta \mathrm{H} 1$ cells by annexin $\mathrm{V}$ binding. Values are means $\pm \mathrm{SEM}$. ${ }^{*} p<0.05$, $n=3-4$. Two-tailed, paired Student's $t$ test. $(\mathbf{k}, \mathbf{l})$ Generation of ROS in cytokine-treated compared with untreated DE cells (k) and SCorganoids (l) with and without addition of L-NNA. Values are means \pm SEM. $* p<0.05, * * p<0.01, * * * p<0.001, n=3-4$. Twotailed, paired Student's $t$ test. (m) Assessment of NO secretion via Griess assay in cytokine-treated vs untreated DE and SC-organoids. Values are means \pm SEM, $n=3-4$. (n-p) Western blot analysis of p38 (n), JNK (o) and ERK (p) phosphorylation

(MAPK) signalling pathways by western blot analysis of JNK, p38 and extracellular-signal regulated kinase (ERK). Exposure to cytokines induced phosphorylation of JNK (Fig. 2o) and p38 (Fig. 2n) after $10 \mathrm{~min}$, which was levelled off again already after $20 \mathrm{~min}$. We did not observe any changes in ERK phosphorylation (Fig. 2p).

The changes at the gene expression level were determined using a whole transcriptome microarray. This was done for SC-beta cells and for different developmental stages and EndoC- $\beta$ H1 cells (Fig. 3a). During the course of differentiation, the number of differentially regulated (fold change $\geq 2$ ) genes increased and the number of intersections of genes differentially regulated in differentiating cells and SC-beta cells, respectively, also increased with their degree of differentiation (Fig. 3b). The intersection of differentially regulated genes of EndoC- $\beta \mathrm{H} 1$ cells and SC-beta cells was smaller compared with that of SC-beta cells and their progenitors. Likewise, the effect of cytokines further increased during differentiation as indicated by the fold changes of the 30 most up- and downregulated genes in the individual developmental stages (ESM Tables 3, 4). A principal component analysis (PCA) resulted in clustering of differentiation stages, demonstrating that the impact of differentiation on the overall transcriptome was higher compared with the impact of cytokine treatment (Fig. 3c). The gene regulation profiles and their overlaps became visible in the heatmap analysis (Fig. 3d). The classification of the different gene clusters can be found in ESM Table 5. Generally, Qiagen Ingenuity Pathway
Analysis (IPA) revealed activation of canonical signalling pathways involved in immune response, inflammation and autoimmune diseases (Fig. 3e). IPA upstream analysis (Fig. 3f) served as a positive control by pointing to the cytokines we used in our analysis and suggested pathways affected in treated cells. Strikingly, regulation of the NF-kB, STAT1 and p38 MAPK signalling pathways was predicted.

In the top 30 jointly regulated genes (Fig. 4a), we searched for genes that were upregulated in SC-beta cells, as well as in at least one other condition, in order to find further genes of interest and a possible conserved pattern. We noticed a number of chemokines, as well as genes of the interferon-induced guanylate-binding protein (GBP) family, genes related to class I antibody processing (TAP1, $P S M B 9)$, an inducer of the inflammatory response system (LTB) and the relatively unknown cytokine $I L 32$. In total, 11 human cytokines were upregulated in our record (Fig. 4b) and 17 human chemokines (Fig. 4c). In addition, we found a number of upregulated genes that are related to the $\mathrm{MHC}$ class I family (Fig. 4d), the activation of the key transcription factors NF- $\mathrm{kB}$ and STAT1 (Fig. 4e) and pattern recognition receptors (PRRs) (Fig. 4f). We did not observe any regulation of cytokine receptors (Fig. 4h) or typical ER stress markers (ATF3, ATF4, ATF6, CHOP [also known as DDIT3], HSPA5, XBP1) in the microarray data. A weak regulation of $C H O P$ and $H S P A 5$ could only be detected in EndoC- $\beta$ H1 cells (Fig. 4g, ESM Fig. 2). A 2D enrichment analysis indicated significantly higher fold changes of genes related to the biological processes 'cytokine-mediated signalling cascades', 'antigen processing' and 'immune response and ER stress' (according to the gene ontology [GO] database) in EndoC- $\beta \mathrm{H} 1$ and SC-beta cells (Fig. 4i, ESM Table 6). The number of regulated genes (ratio) in the corresponding GO terms was partially similar for SC-beta cells and EndoC- $\beta \mathrm{H} 1$ cells, but there were also differences, e.g. with regard to mitosis and cell cycle (Fig. 4i). Overall, a comparison of our transcriptome analysis with RNA sequencing (RNA-seq) data from cytokine-treated (48 h) human islets [26] showed similarities between SC-beta cells and human islets (ESM Tables 7-11, ESM Fig. 3).

Alongside, we reviewed gene expression changes of candidate genes using real-time quantitative PCR with reverse transcription (RT-qPCR) in order to verify the technical stability of the microarray. These genes comprised the cytokines IL32, TNFA (at day 28 [d28] just below the detection threshold of the microarray) and $I L 1 B$; the chemokines $C X C L 9$ and 10 , and $G B P 1$; the ER stress markers $X B P 1 s$ and $C H O P$; and NOS2 and $S O D 2$ as indicators of cellular response to oxidative stress. First, we measured the gene expression changes during the course of differentiation, comparing untreated cells and cytokine-treated cells (Fig. 5a-i). TNFA was most strongly expressed by multipotent pancreatic progenitors (multipotent pancreatic progenitor cells [MPCs], d14) after cytokine 
a

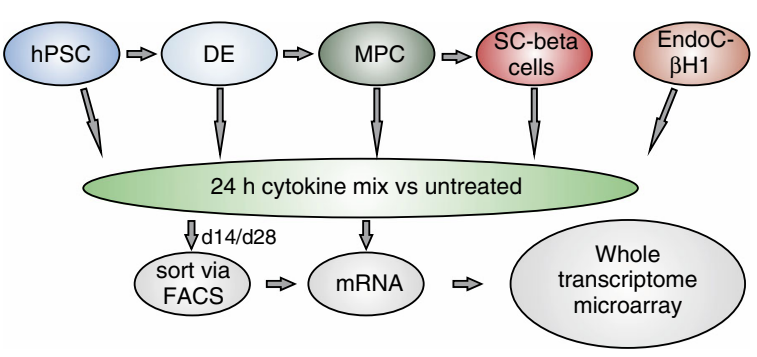

C

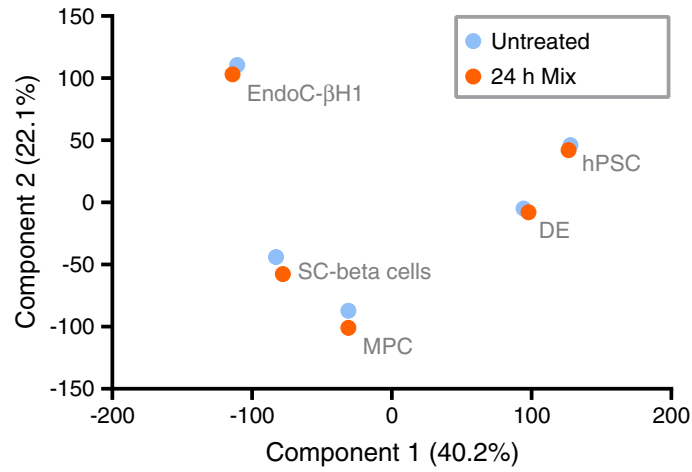

b
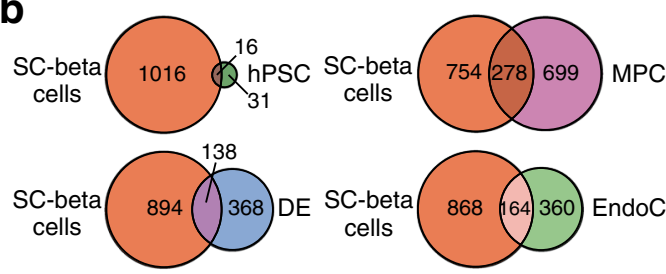

SC-beta
cells 668 (164) EndoC- $\beta \mathrm{H} 1$

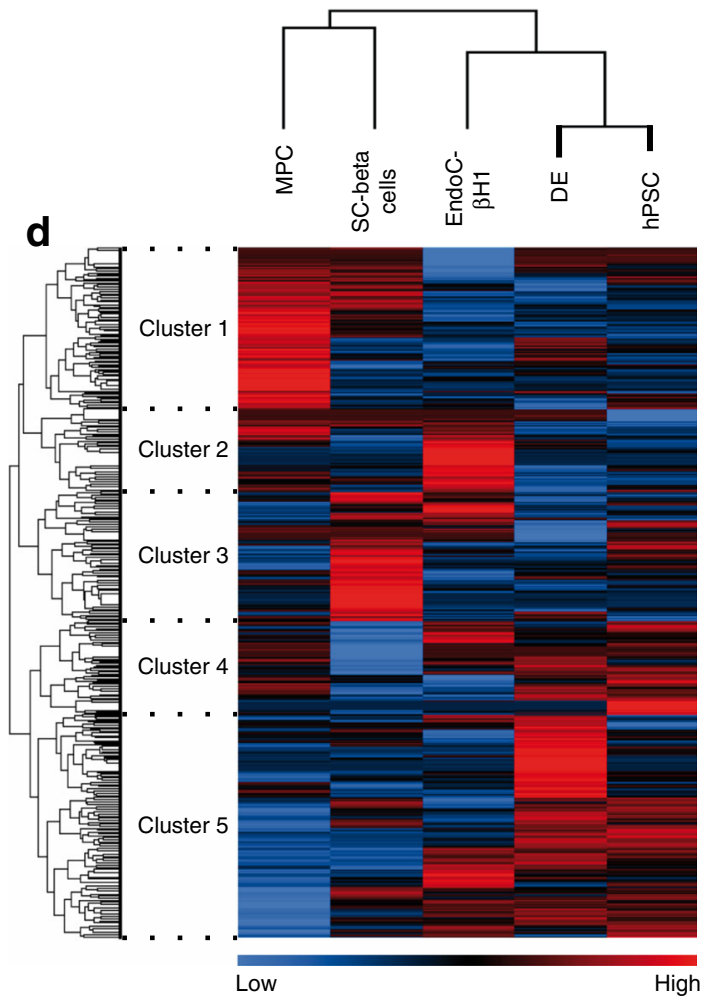

d

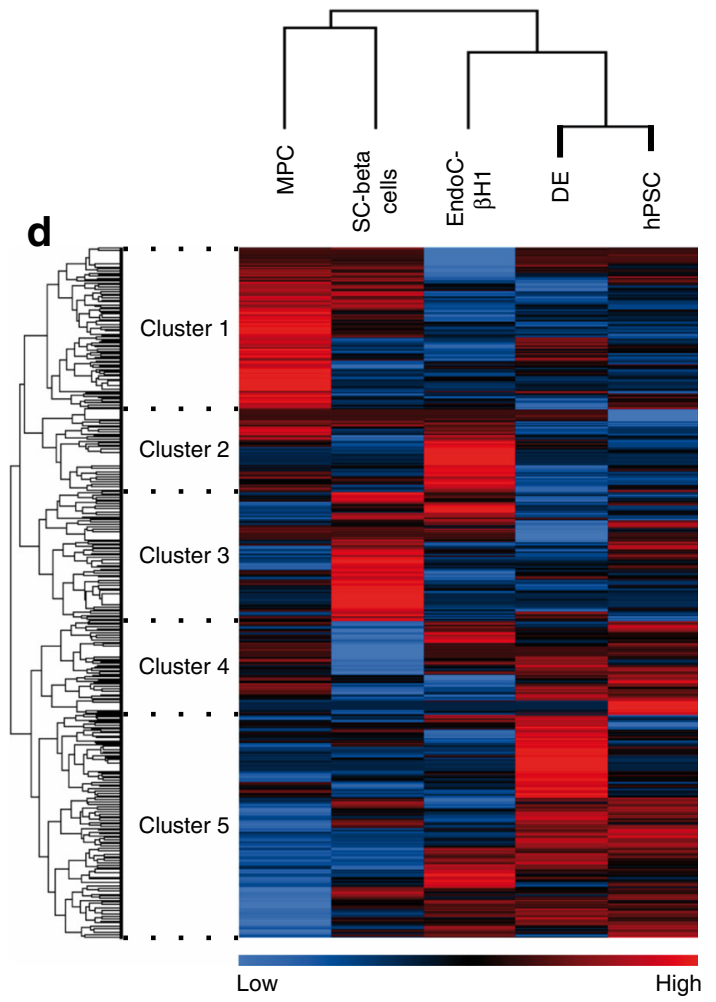

e

Activation $z$ score

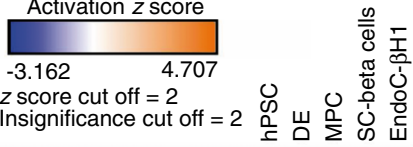

Systemic Lupus Erythematosus In B cell Signalling Pathway Dendritic Cell Maturation

Neuroinflammation Signalling Pathway

Interferon Signalling

IL-17 Signalling

TREM1 Signalling

Crosstalk between Dendritic Cells and Natural Killer Cells

Antioxidant Action of Vitamin C

Necroptosis Signalling Pathway

IL-15 Signalling

Death Receptor Signalling

Production of Nitric Oxide and Reactive Oxygen Species in Macrophages .

Retinoic acid Mediated Apoptosis Signalling

Osteoarthritis Pathway

Acute Phase Response Signalling

IL-15 Production

Type I Diabetes Mellitus Signalling

PI3K Signalling in B Lymphocytes

Role of NFAT in Regulation of the Immune Response

Th17 Activation Pathway

Role of IL-17A in Psoriasis

HMGB1 Signalling

IL-17A Signalling in Airway Cells

Role of IL-17F in Allergic Inflammatory Airway Diseases

Systemic Lupus Erythematosus In T Cell Signalling Pathway 
4Fig. 3 Analysis of transcriptome microarray data. (a) Schematic description of sample generation for the transcriptome analysis. (b) Number of genes jointly regulated (fold change $\geq 2$ ) with SC-beta cells over the course of differentiation and in comparison with EndoC- $\beta \mathrm{H} 1$ cells, after a $24 \mathrm{~h}$ cytokine exposure. (c) PCA of the generated transcriptome data. (d) Hierarchical clustering of expression fold changes of cytokine-treated cells during the different stages of differentiation and EndoC- $\beta \mathrm{H} 1$ cells. (e) Comparative canonical pathway analysis of hPSCs (d0), DE (d4), MPCs (d14), SC-beta cells (d28) and EndoC- $\beta$ H1 cells after cytokine treatment calculated by IPA. (f) IPA upstream analysis of cytokine-treated hPSCs, DE, MPCs, SC-beta cells and EndoC- $\beta \mathrm{H} 1$ cells. EIF2AK2, eukaryotic translation initiation factor 2 alpha kinase 2; HMGB1, high mobility group box 1; IFNA2, interferon alpha 2; IFNG, interferon gamma; IFNL1, interferon lamda 1; IL1A, interleukin 1 alpha; IL1B, interleukin 1 beta; NFAT, NFAT nuclear factor; PI3K, phosphatidylinositol 3-kinase; PRL, prolactin; $\mathrm{RC} 3 \mathrm{H} 1$, ring finger and CCCH-type domains 1; RELA, RELA protooncogene, NF-kB subunit; SMARCA4, SWI/SNF related, matrix associated, actin dependent regulator of chromatin, subfamily a, member 4; TGM2, transglutaminase 2; Th17, T-helper 17; TREM1, triggering receptor expressed on myeloid cells 1

incubation, whereas $I L 1 B, C X C L 9, C X C L 10$ and $X B P 1 s$ were most pronounced in the cytokine-treated SC-beta cells. NOS 2 and SOD2 were only upregulated in SC-beta cells after cytokine treatment, but we found a very high initial level of expression for NOS2 and SOD2 in DE cells, although there was no upregulation of either. Besides the regulation of $X B P 1 s$, we could not detect any regulation of other typical ER stress markers in SC-beta cells (ESM Fig. 2). Next, we compared the basal expression and upregulation of the genes in $\mathrm{mCherry}^{+} / \mathrm{SC}$-beta cells with mCherry ${ }^{-}$/non-insulinproducing cells and EndoC- $\beta \mathrm{H} 1$ cells (Fig. $5 \mathrm{j}-\mathrm{q}$ ), which revealed the regulation of all considered candidate genes also in non-insulin-producing cells.

The cytokine $I L 32$, which we noticed in the group of the top 30 jointly regulated genes with SC-beta cells in all differentiation stages (Fig. 4a), was most strongly expressed in MPCs (d14) treated with cytokines for $24 \mathrm{~h}$ (Fig. 6a). We found almost no expression of this cytokine in untreated cells of all types. In a comparative analysis, cytokines induced the expression of IL32 most in the non-insulin-producing population. In our conditions, EndoC- $\beta \mathrm{H} 1$ cells did not express $I L 32$ after a $24 \mathrm{~h}$ cytokine treatment (Fig. 6b). When examining the medium supernatants from SC-organoids in comparison with EndoC- $\beta \mathrm{H} 1$ cells, we found IL-32 secretion only in supernatants of $24 \mathrm{~h}$ cytokine-treated SC-organoids (Fig. 6c). With regard to apoptosis, no significant increase in caspase 3/7 activation could be detected by exposure to IL-32 alone, or in combination with the cytokine mix (Fig. 6d).

\section{Discussion}

The pathogenesis of autoimmune diabetes involves activation of a variety of immune cells and secretion of inflammatory mediators, which leads to the decrease of beta cell mass in patients with type 1 diabetes. In this study, we exposed hPSCs, DE cells, purified MPCs and SC-beta cells to proinflammatory cytokines and determined transcriptional changes and the mode of cell death. We observed the respective cytokine receptor expressions in all of these cell types. The strong expression of ILIRI in purified SC-beta cells is of particular interest, since human islet beta cells are known to be particularly sensitive to IL-1 $\beta$-mediated beta cell destruction [27-30].

According to our analysis, the cellular response to proinflammatory cytokines increased with the degree of differentiation of the cells. Using our reporter cell line, we were able to differentiate between insulin-producing SC-beta cells and non-insulin-producing cells. A $24 \mathrm{~h}$ treatment with proinflammatory cytokines led to apoptosis of SC-beta cells, but not of the non-insulin-producing population. Similarly, SC-beta cells were more sensitive to cytokines than the human beta cell line EndoC- $\beta \mathrm{H} 1$, which is known for its delayed cytokine sensitivity mode [10, 31]. However, it should be noted that the sensitivity of EndoC- $\beta \mathrm{H} 1$ cells to proinflammatory cytokines depends on the composition of the cytokine mix used as well as the cultivation conditions. A higher cell density can lead to a higher sensitivity [32]. Additionally, EndoC- $\beta \mathrm{H} 1$ pseudoislets showed earlier and greater sensitivity to cytokine toxicity than EndoC- $\beta \mathrm{H} 1$ monolayers [31]. Importantly, human islets require cytokine exposure for several days to induce functional impairment and apoptosis [33]. We therefore assume that SC-beta cells with their immature phenotype are even more sensitive to cytokines than adult beta cells.

Apoptosis in SC-beta cells was mediated both by activation of the caspase 8-mediated extrinsic apoptosis signalling pathway likely triggered by TNF- $\alpha$ receptor binding, and by activation of the caspase 9-mediated intrinsic pathway. The observed low NOS2 induction in SC-beta cells does not appear to be sufficient to produce NO to any significant extent after $24 \mathrm{~h}$, and therefore it excludes the role of $\mathrm{NO}$ in the activation of early cytokine toxicity in these cells. This is in line with observations made in cytokine-treated EndoC- $\beta \mathrm{H} 1$ cells $[10,31,34]$ and a minor role of $\mathrm{NO}$ in cytokine toxicity in human islets $[27,35,36]$. The induction of SC-beta cell apoptosis is more likely to take place via FAS-associated death domain (FADD) and/or stress-signalling pathways, such as JNK or p38, whose activation was detected shortly after cytokine addition. Moreover, induction of ROS generation after $24 \mathrm{~h}$ of cytokine exposure in SC-beta cells might also activate the intrinsic apoptosis signalling pathway [37] and participate in the rapid induction of apoptosis, additionally to ROS-mediated damage of cellular components. Thus we detected many similarities in the common mechanisms of cytokine toxicity between SC-beta cells, EndoC- $\beta \mathrm{H} 1$ cells $[10,31,38]$ and human islets [26]; however, differences in time-line and magnitude of response are also apparent. 
a

\begin{tabular}{|c|c|c|c|c|c|c|c|c|c|c|c|}
\hline & $\begin{array}{l}0 \\
W \\
0 \\
\text { I }\end{array}$ & 㟔 & $\begin{array}{l}0 \\
\Sigma \\
\Sigma\end{array}$ & 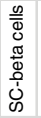 & 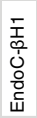 & & $\begin{array}{l}0 \\
\mathbb{W} \\
0 \\
\text { 工 }\end{array}$ & 㟔 & $\begin{array}{l}0 \\
\frac{0}{\Sigma}\end{array}$ & 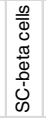 & 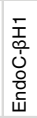 \\
\hline BIRC3 & - & • & 5.3 & 5.9 & 2.1 & $E B / 3$ & 2 & 3.2 & 3.7 & 6.4 & - \\
\hline C3 & • & • & 3.2 & 5.5 & • & ETV7 & - & 1.8 & 3.6 & 5 & 6.7 \\
\hline C6orf222 & • & $\bullet$ & 2.9 & 4.6 & $\bullet$ & GBP1 & • & 3.8 & 5.6 & 7 & 8.6 \\
\hline CCL2 & • & 1.3 & 5.4 & 4.8 & • & GBP2 & • & 3.1 & 3.4 & 6.3 & 2.7 \\
\hline CCL2O & • & - & 2.6 & 8.4 & • & GBP5 & $\bullet$ & $\bullet$ & 6.1 & 6.2 & 6.1 \\
\hline CXCL1 & 2.1 & 4.4 & 3.8 & 4.5 & 1.3 & HCG26 & $\bullet$ & $\bullet$ & 4.2 & 4.5 & $\bullet$ \\
\hline CXCL2 & • & 4.3 & 3.4 & 4.8 & 1.3 & ICAM1 & $\bullet$ & 3 & 7 & 5.3 & 4.6 \\
\hline CXCL3 & $\bullet$ & 3.9 & 3.9 & 5 & 1.1 & IFI27 & • & 1.8 & 2.6 & 4.7 & 4.9 \\
\hline CXCL5 & 1.1 & 3.2 & 3.6 & 5.7 & • & IL32 & 2.1 & 4.7 & 5.9 & 5 & $\bullet$ \\
\hline CXCL6 & • & • & 4.1 & 4.9 & 1 & LTB & 5.6 & 4.7 & 4.5 & 5.6 & 1.7 \\
\hline CXCL8 & • & • & 4.8 & 5.3 & • & MMP7 & $\bullet$ & $\bullet$ & 3.8 & 4.8 & - \\
\hline$C X C L 9$ & $\bullet$ & • & 6.1 & 7 & 8.7 & PSMB9 & $\bullet$ & 4.8 & 7.6 & 6.1 & 8.3 \\
\hline CXCL10 & $\bullet$ & $\bullet$ & 4.4 & 8.6 & 6.6 & TAP1 & $\bullet$ & 5.6 & 6.5 & 4.9 & 6.3 \\
\hline CXCL11 & $\bullet$ & $\bullet$ & 5.8 & 6.5 & 2.1 & TRIM22 & $\bullet$ & 1.5 & 2.4 & 4.6 & 2.5 \\
\hline$D E F B 4 A$ & • & 3.3 & 1.9 & 8.1 & • & USP $30-A S 1$ & $\bullet$ & $\bullet$ & 3.9 & 4.6 & 7.2 \\
\hline
\end{tabular}

b

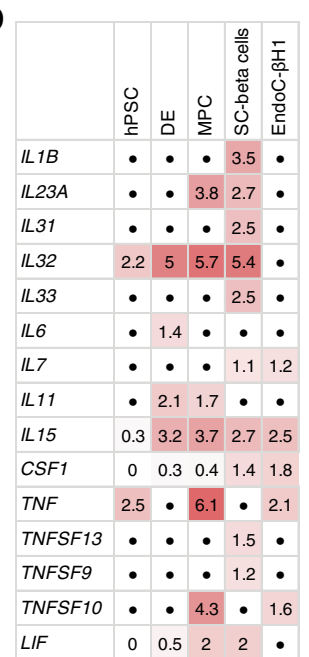

C

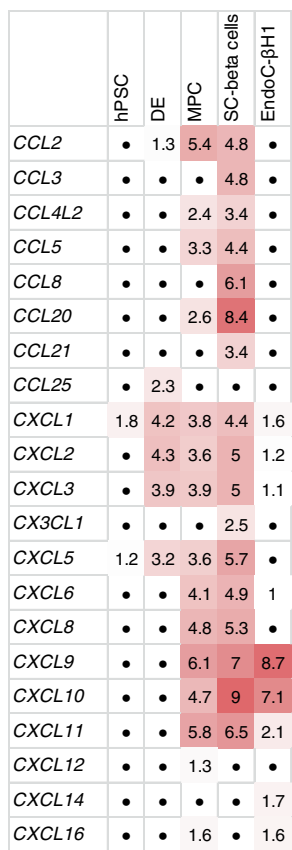

d

\begin{tabular}{|c|c|c|c|c|c|}
\hline & $\begin{array}{l}0 \\
W \\
0 \\
\text { C }\end{array}$ & 㟔 & $\begin{array}{l}0 \\
\Sigma \\
\Sigma\end{array}$ & 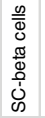 & 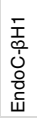 \\
\hline$H L A-A$ & 0 & 1.4 & 2.6 & 1.7 & 3.3 \\
\hline$H L A-B$ & 0.2 & 1.4 & 4 & 2.1 & 6.6 \\
\hline$H L A-C$ & 0.1 & 1 & 1.3 & 0.9 & 3.9 \\
\hline$H L A-E$ & 0.1 & 1.4 & 2.5 & 1.9 & 3.9 \\
\hline$H L A-F$ & 0.3 & 2.5 & 5.2 & 4.1 & 8 \\
\hline$H L A-G$ & 0.1 & 1.3 & 2.3 & 1.5 & 3.7 \\
\hline TAP1 & 0.6 & 5.6 & 6.5 & 4.9 & 6.3 \\
\hline TAP2 & 0.3 & 4.4 & 5.2 & 3.6 & 4.5 \\
\hline TAPBP & 0.4 & 2.7 & 3.2 & 1.5 & 2.3 \\
\hline ERAP1 & 0.3 & 0.8 & 2.3 & 0.9 & 1.5 \\
\hline ERAP2 & 1.1 & 5.1 & 6.8 & 3.7 & 3.8 \\
\hline$B 2 M$ & 0.7 & 4.7 & 3.2 & 1.7 & 2.4 \\
\hline PSMB9 & 0.8 & 4.8 & 7.7 & 6.1 & 8.3 \\
\hline
\end{tabular}

e (n) f

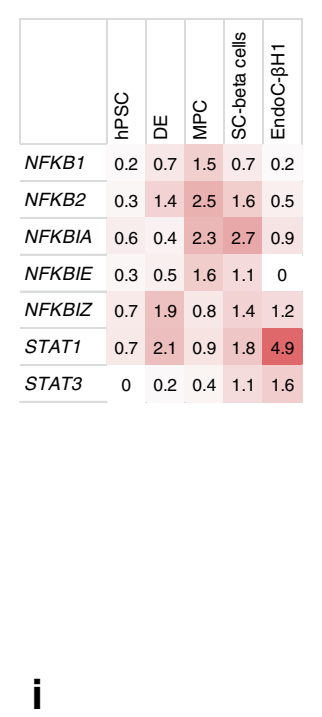

g

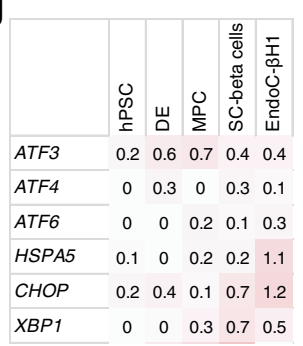

IFNGR1 I $\begin{array}{lllllll}\text { IFNGR2 } & 0 & 0.2 & 0.9 & 0.8 & 0.2\end{array}$ $\begin{array}{lllllll}\text { TNFR1 } & 0.1 & 0.3 & 0.4 & 0.6 & \bullet\end{array}$ \begin{tabular}{ll|lllll} 
ILIR1 & $\bullet$ & -1 & 0 & 0.3 & ・
\end{tabular}

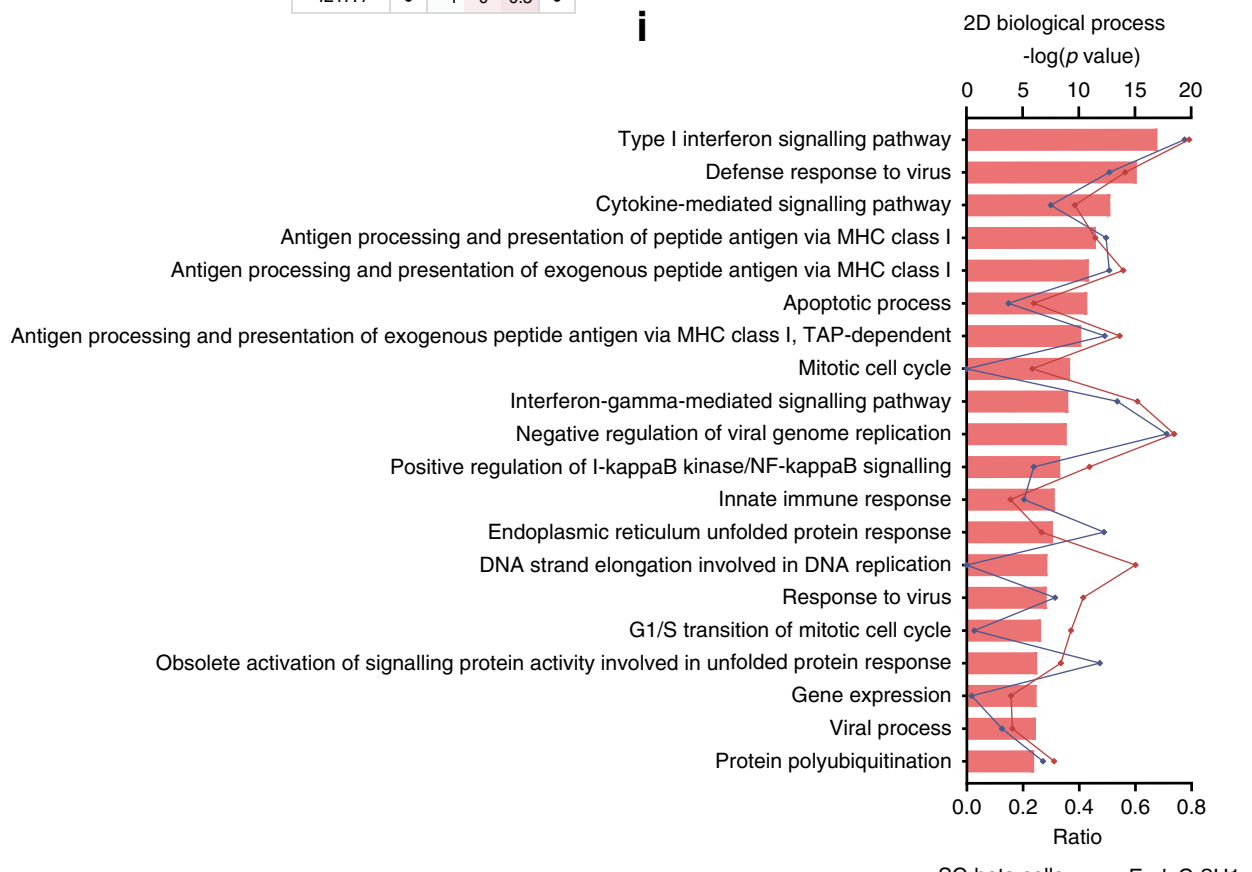

$\rightarrow$ SC-beta cells $\rightarrow$ EndoC-BH1 
Fig. 4 Summary of differentially regulated genes and pathways. (a) Top 30 jointly with SC-beta cells upregulated (fold change $\geq 2$ ) genes of hPSCs, DE, MPCs and EndoC- $\beta$ H1 cells (represented as $\log _{2}$ fold change; black circle, below threshold) after a $24 \mathrm{~h}$ cytokine treatment. Comparative tables of upregulated cytokines (b), chemokines (c), members of the MHC class I family (d), NF-kB- and STAT1-pathwayrelated genes (e), PRRs (f), typical ER stress markers (g) and cytokine receptors (h) after $24 \mathrm{~h}$ of cytokine treatment (represented as $\log _{2}$ fold change; black circle, below threshold). (i) $2 \mathrm{D}$ enrichment analysis of genes regulated in EndoC- $\beta \mathrm{H} 1$ and SC-beta cells according to the GO term 'biological process'. The ratio represents the number of regulated genes related to the different biological processes

Analysis of the microarray data revealed the central importance of the NF-KB and STAT1 signalling pathways for the cellular effects, resulting in the expression of PRRs, MHC-I genes and a large range of cytokines and chemokines. In human islets, EndoC- $\beta \mathrm{H} 1$ cells and pancreases of recently diagnosed type 1 diabetes patients, the activation of NF-KB was shown to be significantly lower than in rodent beta cells and not primarily responsible for cytokine-mediated beta cell death [31, 39]. Using gene set enrichment analysis (GSEA) and analysis of enriched pathways, we were able to uncover a clear relation to cytokine-induced, inflammatory and immunomodulatory signalling pathways. The differential regulation of many genes in SC-beta cells often developed in progenitor stages and generally increased with the degree of differentiation. In conclusion, the progenitor populations are also potentially capable of communication with the immune system, although cytokine toxicity is less pronounced in these cells. Induction of cytokines and chemokines in cytokine-treated SC-beta cells was particularly striking. We detected a total of 12 cytokines, including IL32, as well as 17 differentially regulated chemokines, including CXCL9 and CXCL10, the secretion of which has been already demonstrated in cytokine-treated pancreatic organoids derived from human induced pluripotent stem cells (iPSCs) and/or human islets $[20,26]$. We observed a stage-dependent increase of $I L I B$ and TNFA expression. $I L I B$ and TNFA expression of SC-beta cells is consistent with findings for human islets [26]. Changes in gene expression do not necessarily result in secretion of bioactive proteins though. The secretion of IL-32, however, was verified in our study. Although we could not observe any IL32 expression in EndoC- $\beta \mathrm{H} 1$ cells after a $24 \mathrm{~h}$ cytokine exposure under present conditions, a cytokine-induced increase in IL32 gene expression has already been demonstrated for these cells in other studies [40]. IL-32 has only recently been identified as an early biomarker in the blood of children from type 1 diabetes-risk families even before autoantibody appearance and diabetes manifestation [40]. IL-32 is known to promote the expression of chemokines and proinflammatory cytokines such as TNF- $\alpha$ and IL- 6 in human and murine immune cells [41]. An increased expression of IL-32 as a result of signals via Toll-like receptor 2 (TLR2), TLR3 and TLR4 has also been shown in human fibroblast-like synoviocytes [41, 42]. In addition, the involvement of IL-32 in the development of other autoimmune diseases, such as rheumatoid arthritis, has already been described [42]. The role of IL-32 in type 1 diabetes is still unclear, but it is possible that IL-32 might be crucially involved in the pathogenesis of autoimmune diabetes [43]. We did not detect a significant IL-32-induced increase in apoptosis in SC-organoids. In EndoC- $\beta \mathrm{H} 1$ cells IL-32 did not appear to directly affect survival of the cells [40]. Thus, IL-32 seems to participate in activating immune cells rather than directly damaging beta cells [40]. In any case, further studies on the role of IL-32 in the development of type 1 diabetes would be worthwhile.

Although our observations are consistent with previous analyses of gene regulation in human islets, it is noteworthy that only one point in time ( $24 \mathrm{~h}$ cytokine exposure) was examined in our study. It is possible that the dynamic regulation of gene expression of relevant cytokine-modulated genes was not recorded by our analysis at other times. For example, the increase in expression of $X B P 1 s$ indicates ER stress, but we were not able to determine any regulation of $C H O P$ or other typical ER stress markers after $24 \mathrm{~h}$. According to GO terms, ER stress and unfolded protein response (UPR)-associated genes were regulated though. In another study on iPSCderived organoids, ER stress occurred only after 48 h of cytokine treatment [20]. Therefore, we suggest that we were only able to depict the beginning of ER stress, which could, however, be increased over time. In conclusion, ER stress does not seem to be of primary importance for the rapid induction of apoptosis, but may play a greater role at later time points. It should also be mentioned here that only three pooled biological replicates were used to determine the microarray data. Increasing the number of biological replicates could therefore lead to clearer results. The stability of our microarray data, however, could be confirmed by the RT-qPCR validation of the candidate genes.

Overall, SC-beta cells are characterised by a similar pattern of differential gene regulation after cytokine exposure as human islets [26]. SC-beta cells are sensitive to cytokines; however, their time-response and sensitivity mode seem to be stronger than that of mature beta cells. The underlying mechanisms of apoptosis induction show many similarities, but require further investigation. We therefore believe that $\mathrm{SC}$-beta cells can be a new attractive in vitro model for human beta cell studies. The immature phenotype of SC-beta cells could represent an interesting model for early-onset type 1 diabetes (EO-T1D). EO-T1D, marked by a fulminant manifestation of type 1 diabetes, is assigned in small children significantly younger than 3 years of age, in whom type 1 diabetes has already been diagnosed [44, 45]. In contrast, 

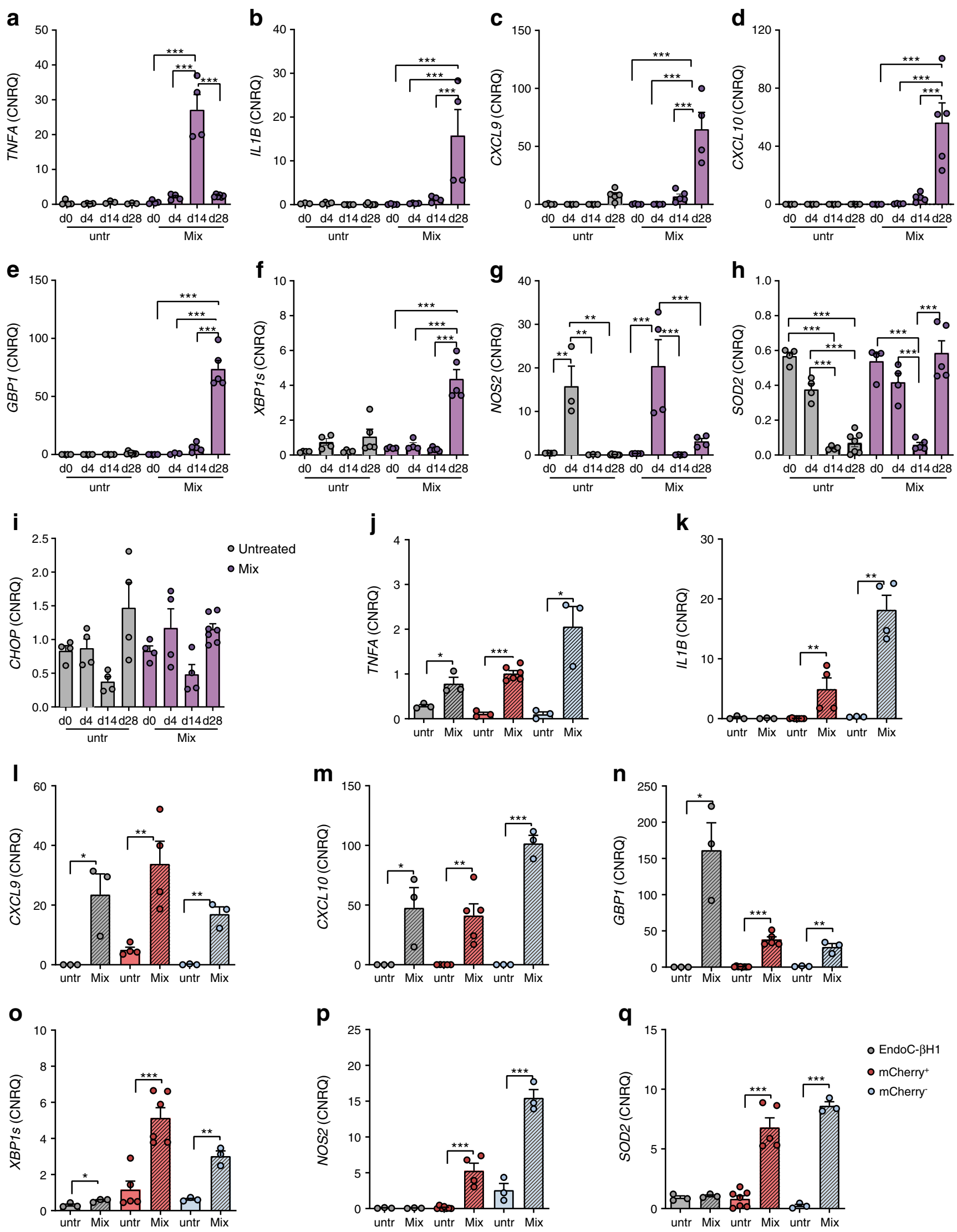
Fig. 5 Validation of candidate gene expression. (a-i) RT-qPCR gene expression analysis of TNFA (a), IL1B (b), CXCL9 (c), CXCL10 (d), GBP1 (e), XBP1s (f), NOS2 (g), SOD2 (h) and CHOP (i) in $24 \mathrm{~h}$ cytokine-treated (Mix) compared with untreated (untr) cells during the differentiation process. Values are means \pm SEM. $* * p<0.01$, $* * * p<0.001, n=3-7$. ANOVA plus Tukey's post-test. $(\mathbf{j}-\mathbf{q})$ Comparative RT-qPCR gene expression analysis of TNFA (j), IL1B (k), CXCL9 (1), CXCL10 (m), GBP1 (n), XBP1s (o), NOS2 (p) and $S O D 2(\mathbf{q})$ in cytokine-treated vs untreated $\mathrm{mCherry}^{+} /$insulinproducing and $\mathrm{mCherry}^{-} /$non-insulin-producing stem cell-derived pancreatic cells and EndoC- $\beta \mathrm{H} 1$ cells. Values are means \pm SEM. ${ }^{*} p<0.05, * * p<0.01, * * * p<0.001, n=3-9$. ANOVA plus Tukey's post-test. Data are represented as calibrated normalised relative quantity (CNRQ) after normalisation with qBase plus

patients with type 1 diabetes manifestation in adulthood can be assigned a slow progressive course [46]. Beta cell loss and disease progression in autoimmune diabetes seem therefore to be age-related: the younger the patient is when the diagnosis is made, the faster and more intensive the disease progression is, and vice versa $[47,48]$.
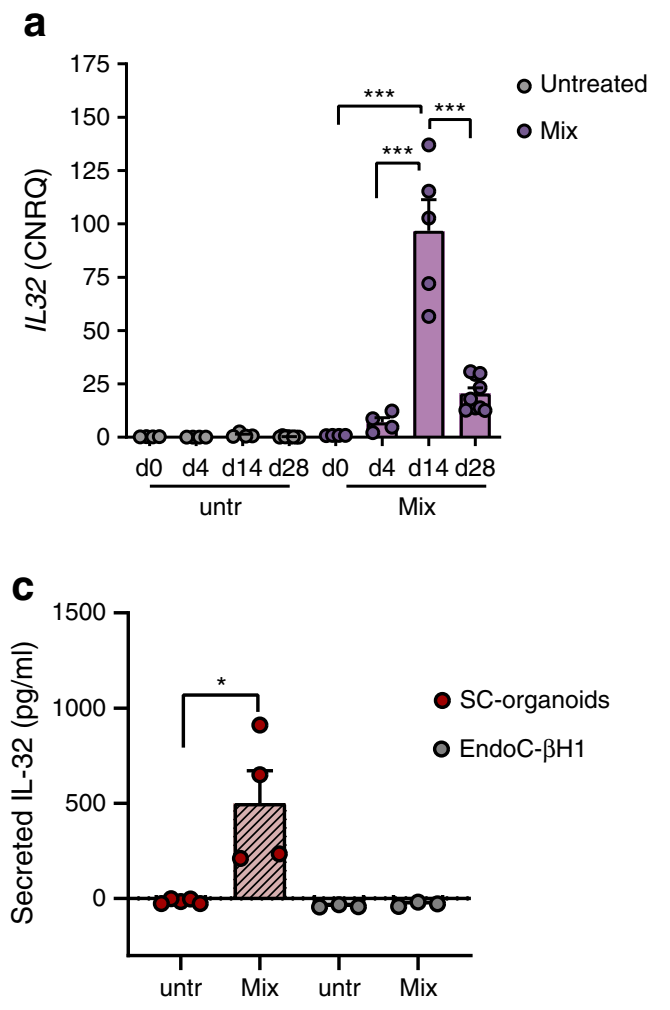

Fig. 6 IL-32 expression and secretion in SC-organoids and IL-32 involvement in apoptosis. (a) RT-qPCR expression analysis of IL32 in 24 h cytokine-treated (Mix) compared with untreated (untr) cells during the differentiation process. Values are means \pm SEM. $* * * p<0.001, n=$ 3-7. ANOVA plus Tukey's post-test. (b) Comparative RT-qPCR expression analysis of IL32 in $24 \mathrm{~h}$ cytokine-treated (Mix) vs untreated (untr) $\mathrm{mCherry}^{+} /$insulin-producing and $\mathrm{mCherry}^{-} /$non-insulin-producing stem cell-derived pancreatic cells and EndoC- $\beta \mathrm{H} 1$ cells. Values are means \pm SEM. $* * p<0.01, * * * p<0.001, n=3-9$. ANOVA plus Tukey's post-test. Data are represented as calibrated normalised relative quantity (CNRQ)
Another interesting aspect of our study is a possible participation of non-insulin-producing pancreatic cells in the acceleration of inflammation. So far, little attention has been paid to non-insulin-producing pancreatic cells and their role in the immune response. A recently published RNA-seq analysis on mouse islets revealed the responsiveness of all endocrine cell types to cytokines despite the selective destruction of beta cells only [49]. In view of the heterogeneity of the cell population obtained after differentiation, it is an invaluable advantage to be able to differentiate between insulin-producing and non-insulin-producing cells when assessing the question of cell type-specific effects. The observed cytokine and chemokine expression of non-insulin-producing cells suggests a possible participation of these cells in the attraction of immune cells and in the destruction process of beta cells. Our data indicate that the cytokine signalling pathways are apparently also activated in these cells, though they are less prone to cytokine toxicity than SC-beta cells. We can therefore conclude that, with the approach of cell replacement therapy using SC-organoids, there may be the possibility of increased
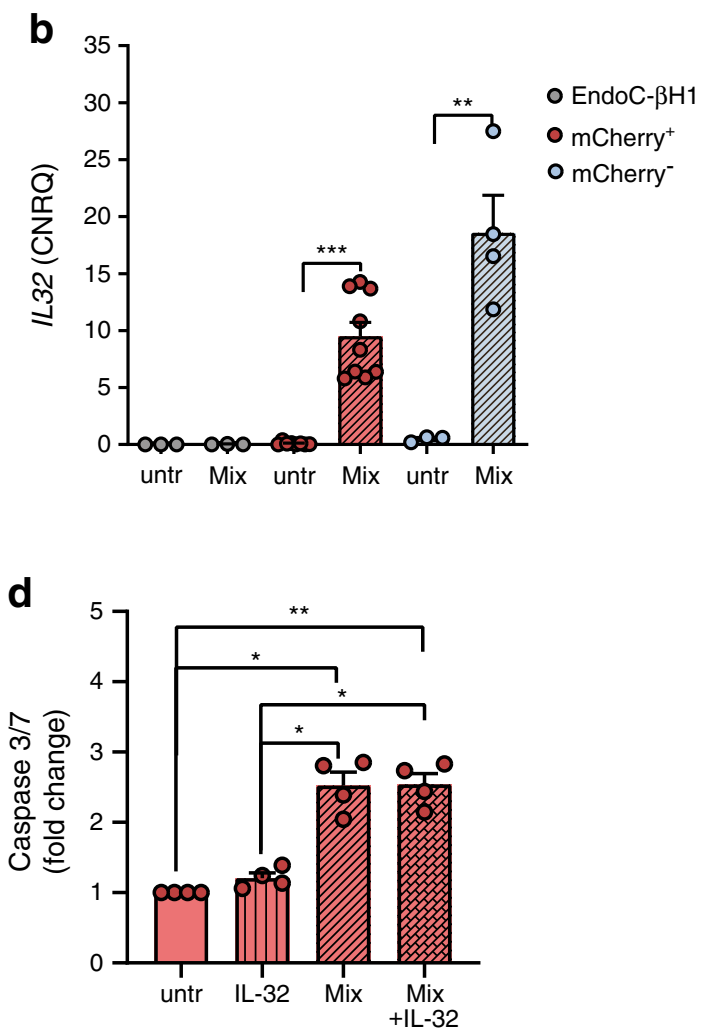

after normalisation with qBase plus. (c) IL-32 secretion detected by ELISA in supernatants from unsorted SC-organoids and EndoC- $\beta \mathrm{H} 1$ cells that were untreated (untr) or cytokine-treated for $24 \mathrm{~h}$ (Mix) in each case. Values are means \pm SEM. $* p<0.05, n=3-5$. Two-tailed, unpaired Student's $t$ test. (d) Activation of Caspase 3/7 in SC-organoids after a $24 \mathrm{~h}$ exposure to IL-32 alone or in addition to the cytokine mix (Mix) compared with untreated (untr) cells. Values are means \pm SEM. $* p<0.05, * * p<0.01, n=4$. Repeated measures (RM) ANOVA with Geisser-Greenhouse correction plus Tukey's post-test 
attraction of immune cells by SC-beta cells and non-insulinproducing cells. Furthermore, cytokine-mediated SC-beta cell death could represent an obstacle, especially in an environment with persistent autoimmunity.

Supplementary Information The online version of this article https://doi. org/10.1007/s00125-022-05654-0 contains peer-reviewed but unedited supplementary material.

Acknowledgements We gratefully acknowledge the technical assistance of J. Baustian and B. Leß. We would also like to acknowledge the assistance of the Cell Sorting Core Facility of the Hannover Medical School supported by the Braukmann-Wittenberg-Herz-Stiftung and the DFG. Microarray data used or referred to in this publication were generated by the Research Core Unit Genomics (RCUG).

Data availability The datasets generated during and/or analysed during the current study are available from the corresponding author on reasonable request.

Funding Open Access funding enabled and organized by Projekt DEAL. This work has been supported by the Deutsche Forschungsgemeinschaft (DFG, German Research Foundation, NA 1285/2-1).

Authors' relationships and activities The authors declare that there are no relationships or activities that might bias, or be perceived to bias, their work.

Contribution statement $\mathrm{RD}$ and $\mathrm{ON}$ contributed to the conceptualisation, design and formal analysis of the manuscript. ON took care of the funding acquisition. All authors took care of the acquisition, analysis and interpretation of data. $\mathrm{RD}, \mathrm{KC}, \mathrm{IN}$ and $\mathrm{ON}$ were responsible for the methodology. ON was responsible for project administration and supervision. Visualisation was carried out by RD, KC, EG-C and ON. RD, IM, EG-C and ON wrote the original draft and EG-C, IM and ON reviewed and edited the manuscript. All authors revised the article critically and approved the final version. ON is the guarantor of the work.

Open Access This article is licensed under a Creative Commons Attribution 4.0 International License, which permits use, sharing, adaptation, distribution and reproduction in any medium or format, as long as you give appropriate credit to the original author(s) and the source, provide a link to the Creative Commons licence, and indicate if changes were made. The images or other third party material in this article are included in the article's Creative Commons licence, unless indicated otherwise in a credit line to the material. If material is not included in the article's Creative Commons licence and your intended use is not permitted by statutory regulation or exceeds the permitted use, you will need to obtain permission directly from the copyright holder. To view a copy of this licence, visit http://creativecommons.org/licenses/by/4.0/.

\section{References}

1. Eizirik DL, Mandrup-Poulsen T (2001) A choice of death-the signal-transduction of immune-mediated beta-cell apoptosis. Diabetologia 44:2115-2133. https://doi.org/10.1007/ s001250100021
2. Cnop M, Welsh N, Jonas J-C, Jörns A, Lenzen S, Eizirik DL (2005) Mechanisms of pancreatic $\beta$-cell death in type 1 and type 2 diabetes. Many differences, few similarities. Diabetes 54(Suppl 2):S97S107

3. Pirot P, Cardozo AK, Eizirik DL (2008) Mediators and mechanisms of pancreatic beta-cell death in type 1 diabetes. Arq Bras Endocrinol Metabol 52:156-165. https://doi.org/10.1590/S000427302008000200003

4. Pavlovic D, Chen MC, Gysemans CA, Mathieu C, Eizirik DL (1999) The role of interferon regulatory factor-1 in cytokineinduced mRNA expression and cell death in murine pancreatic beta-cells. Eur Cytokine Netw 10:403-412

5. Larsen CM, Wadt KA, Juhl LF et al (1998) Interleukin-1betainduced rat pancreatic islet nitric oxide synthesis requires both the p38 and extracellular signal-regulated kinase $1 / 2$ mitogen-activated protein kinases. J Biol Chem 273:15294-15300. https://doi.org/10. 1074/jbc.273.24.15294

6. Eizirik DL, Flodström M, Karlsen AE, Welsh N (1996) The harmony of the spheres: inducible nitric oxide synthase and related genes in pancreatic beta cells. Diabetologia 39:875-890. https://doi.org/ 10.1007/BF00403906

7. Whitmarsh AJ, Yang SH, Su MS, Sharrocks AD, Davis RJ (1997) Role of p38 and JNK mitogen-activated protein kinases in the activation of ternary complex factors. Mol Cell Biol 17:2360-2371. https://doi.org/10.1128/MCB.17.5.2360

8. Eizirik DL, Colli ML, Ortis F (2009) The role of inflammation in insulitis and beta-cell loss in type 1 diabetes. Nat Rev Endocrinol 5: 219-226. https://doi.org/10.1038/nrendo.2009.21

9. Russell MA, Redick SD, Blodgett DM et al (2019) HLA class II antigen processing and presentation pathway components demonstrated by transcriptome and protein analyses of islet $\beta$-cells from donors with type 1 diabetes. Diabetes 68:988-1001. https://doi.org/ $10.2337 / \mathrm{db} 18-0686$

10. Brozzi F, Nardelli TR, Lopes M et al (2015) Cytokines induce endoplasmic reticulum stress in human, rat and mouse beta cells via different mechanisms. Diabetologia 58:2307-2316. https://doi. org/10.1007/s00125-015-3669-6

11. Eizirik DL, Pipeleers DG, Ling Z, Welsh N, Hellerström C, Andersson A (1994) Major species differences between humans and rodents in the susceptibility to pancreatic beta-cell injury. Proc Natl Acad Sci U S A 91:9253-9256

12. Russ HA, Parent AV, Ringler JJ et al (2015) Controlled induction of human pancreatic progenitors produces functional beta-like cells in vitro. EMBO J 34:1759-1772. https://doi.org/10.15252/embj. 201591058

13. Pagliuca FW, Millman JR, Gürtler M et al (2014) Generation of functional human pancreatic $\beta$ cells in vitro. Cell 159:428-439. https://doi.org/10.1016/j.cell.2014.09.040

14. Bruin JE, Erener S, Vela J et al (2014) Characterization of polyhormonal insulin-producing cells derived in vitro from human embryonic stem cells. Stem Cell Res 12: 194-208. https://doi.org/ 10.1016/j.scr.2013.10.003

15. Melton D (2021) The promise of stem cell-derived islet replacement therapy. Diabetologia 64:1030-1036. https://doi.org/10.1007/ s00125-020-05367-2

16. Rezania A, Bruin JE, Arora P et al (2014) Reversal of diabetes with insulin-producing cells derived in vitro from human pluripotent stem cells. Nat Biotechnol 32:1121-1133. https://doi.org/10.1038/ nbt.3033

17. Vegas AJ, Veiseh O, Gurtler M et al (2016) Long-term glycemic control using polymer-encapsulated human stem cell-derived beta cells in immune-competent mice. Nat Med 22:306-311. https://doi. org $/ 10.1038 / \mathrm{nm} .4030$

18. Desai T, Shea LD (2017) Advances in islet encapsulation technologies. Nat Rev Drug Discov 16:338-350. https://doi.org/10.1038/ nrd.2016.232 
19. Barkai U, Rotem A, de Vos P (2016) Survival of encapsulated islets: more than a membrane story. World J Transplant 6:69-90. https://doi.org/10.5500/wjt.v6.i1.69

20. Demine S, Schiavo AA, Marín-Cañas S, Marchetti P, Cnop M, Eizirik DL (2020) Pro-inflammatory cytokines induce cell death, inflammatory responses, and endoplasmic reticulum stress in human iPSC-derived beta cells. Stem Cell Res Ther 11:7

21. Veres A, Faust AL, Bushnell HL et al (2019) Charting cellular identity during human in vitro $\beta$-cell differentiation. Nature 569: 368-373. https://doi.org/10.1038/s41586-019-1168-5

22. Dettmer R, Niwolik I, Mehmeti I, Jörns A, Naujok O (2021) New hPSC SOX9 and INS reporter cell lines facilitate the observation and optimization of differentiation into insulin-producing cells. Stem Cell Rev Rep 17:2193-2209. https://doi.org/10.1007/ s12015-021-10232-9

23. Gurgul-Convey E, Kaminski MT, Lenzen S (2015) Physiological characterization of the human EndoC- $\beta \mathrm{H} 1 \beta$-cell line. Biochem Biophys Res Commun 464:13-19. https://doi.org/10.1016/j.bbrc. 2015.05.072

24. Grunnet LG, Aikin R, Tonnesen MF et al (2009) Proinflammatory cytokines activate the intrinsic apoptotic pathway in $\beta$-cells. Diabetes 58:1807-1815. https://doi.org/10.2337/db08-0178

25. Ravassard P, Hazhouz Y, Pechberty S et al (2011) A genetically engineered human pancreatic $\beta$ cell line exhibiting glucoseinducible insulin secretion. J Clin Invest 121:3589-3597. https:// doi.org/10.1172/JCI58447

26. Eizirik DL, Sammeth M, Bouckenooghe T et al (2012) The human pancreatic islet transcriptome: expression of candidate genes for type 1 diabetes and the impact of pro-inflammatory cytokines. PLoS Genet 8:e1002552. https://doi.org/10.1371/journal.pgen. 1002552

27. Mandrup-Poulsen T (1996) The role of interleukin-1 in the pathogenesis of IDDM. Diabetologia 39:1005-1029. https://doi.org/10. 1007/BF00400649

28. Bendtzen K, Mandrup-Poulsen T, Nerup J, Nielsen JH, Dinarello CA, Svenson M (1986) Cytotoxicity of human pI 7 interleukin-1 for pancreatic islets of Langerhans. Science 232:1545-1547. https://doi.org/10.1126/science.3086977

29. Corbett JA, Lancaster JR Jr, Sweetland MA, McDaniel ML (1991) Interleukin-1 beta-induced formation of EPR-detectable ironnitrosyl complexes in islets of Langerhans. Role of nitric oxide in interleukin-1 beta-induced inhibition of insulin secretion. J Biol Chem 266:21351-21354. https://doi.org/10.1016/S0021-9258(18) 54642-1

30. Eizirik DL, Tracey DE, Bendtzen K, Sandler S (1991) An interleukin-1 receptor antagonist protein protects insulinproducing beta cells against suppressive effects of interleukin-1 beta. Diabetologia 34:445-448. https://doi.org/10.1007/ BF00403185

31. Gurgul-Convey E, Mehmeti I, Plötz T, Jörns A, Lenzen S (2016) Sensitivity profile of the human EndoC- $\beta \mathrm{H} 1$ beta cell line to proinflammatory cytokines. Diabetologia 59:2125-2133. https://doi.org/ 10.1007/s00125-016-4060-y

32. Tsonkova VG, Sand FW, Wolf XA et al (2018) The EndoC- $\beta \mathrm{H} 1$ cell line is a valid model of human beta cells and applicable for screenings to identify novel drug target candidates. Mol Metab 8: 144-157. https://doi.org/10.1016/j.molmet.2017.12.007

33. Delaney CA, Pavlovic D, Hoorens A, Pipeleers DG, Eizirik DL (1997) Cytokines induce deoxyribonucleic acid strand breaks and apoptosis in human pancreatic islet cells. Endocrinology 138:2610 2614. https://doi.org/10.1210/endo.138.6.5204

34. Oleson BJ, McGraw JA, Broniowska KA et al (2015) Distinct differences in the responses of the human pancreatic $\beta$-cell line
EndoC- $\beta \mathrm{H} 1$ and human islets to proinflammatory cytokines. Am J Physiol Regul Integr Comp Physiol 309:R525-R534. https://doi. org/10.1152/ajpregu.00544.2014

35. Eizirik DL, Sandler S, Welsh N et al (1994) Cytokines suppress human islet function irrespective of their effects on nitric oxide generation. J Clin Invest 93:1968-1974. https://doi.org/10.1172/ JCI1 17188

36. Rabinovitch A, Suarez-Pinzon WL, Strynadka K et al (1994) Human pancreatic islet beta-cell destruction by cytokines is independent of nitric oxide production. J Clin Endocrinol Metab 79: 1058-1062. https://doi.org/10.1210/jcem.79.4.7962274

37. Lenzen S (2008) Oxidative stress: the vulnerable beta-cell. Biochem Soc Trans 36:343-347. https://doi.org/10.1042/ BST0360343

38. Fred RG, Kappe C, Ameur A et al (2015) Role of the AMP kinase in cytokine-induced human EndoC- $\beta \mathrm{H} 1$ cell death. Mol Cell Endocrinol 414:53-63. https://doi.org/10.1016/j.mce.2015.07.015

39. Hindlycke H, Lu T, Welsh N (2012) Cytokine-induced human islet cell death in vitro correlates with a persistently high phosphorylation of STAT-1, but not with NF-kB activation. Biochem Biophys Res Commun 418:845-850. https://doi.org/10.1016/j.bbrc.2012. 01.130

40. Kallionpää H, Somani J, Tuomela S et al (2019) Early detection of peripheral blood cell signature in children developing $\beta$-cell autoimmunity at a young age. Diabetes 68:2024-2034. https://doi.org/ 10.2337/db19-0287

41. Kim SH, Han SY, Azam T, Yoon DY, Dinarello CA (2005) Interleukin-32: a cytokine and inducer of TNFalpha. Immunity 22:131-142. https://doi.org/10.1016/j.immuni.2004.12.003

42. Alsaleh G, Sparsa L, Chatelus E et al (2010) Innate immunity triggers IL-32 expression by fibroblast-like synoviocytes in rheumatoid arthritis. Arthritis Res Ther 12:R135. https://doi.org/10.1186/ ar3073

43. de Albuquerque R, Komsi E, Starskaia I, Ullah U, Lahesmaa R (2021) The role of Interleukin-32 in autoimmunity. Scand J Immunol 93:e13012

44. Rewers M, Hyöty H, Lernmark $\AA$ et al (2018) The environmental determinants of diabetes in the young (TEDDY) study: 2018 update. Curr Diab Rep 18:136

45. Sales Luis M, Alcafache M, Ferreira S et al (2019) Children with type 1 diabetes of early age at onset - immune and metabolic phenotypes. J Pediatr Endocrinol Metab 32:935-941. https://doi.org/10. 1515/jpem-2019-0103

46. Buzzetti R, Zampetti S, Maddaloni E (2017) Adult-onset autoimmune diabetes: current knowledge and implications for management. Nat Rev Endocrinol 13:674-686. https://doi.org/10.1038/ nrendo.2017.99

47. Johnson MB, Patel KA, De Franco E et al (2020) Type 1 diabetes can present before the age of 6 months and is characterised by autoimmunity and rapid loss of beta cells. Diabetologia 63:26052615. https://doi.org/10.1007/s00125-020-05276-4

48. Barker A, Lauria A, Schloot N et al (2014) Age-dependent decline of $\beta$-cell function in type 1 diabetes after diagnosis: a multi-Centre longitudinal study. Diabetes Obes Metab 16:262-267. https://doi. org/10.1111/dom.12216

49. Stancill JS, Kasmani MY, Khatun A, Cui W, Corbett JA (2021) Single-cell RNA sequencing of mouse islets exposed to proinflammatory cytokines. Life Sci Alliance 4:e202000949. https://doi.org/ $10.26508 /$ lsa.202000949

Publisher's note Springer Nature remains neutral with regard to jurisdictional claims in published maps and institutional affiliations. 